\title{
SPECTROPHOTOMETRIC DETERMINATION OF NITRITE BY ITS CATALYTIC EFFECT ON THE OXIDATION OF CONGO RED WITH BROMATE
}

\author{
Zenovia Moldovan ${ }^{*}$ \\ University of Bucharest, Faculty of Chemistry, Department of Analytical Chemistry, \\ 90-92 Panduri Road, 050663-Bucharest, Romania
}

(Received December 21, 2010; revised February 3, 2012)

\begin{abstract}
A novel simple, sensitive and rapid kinetic-spectrophotometric method for the determination of trace amounts of nitrite is proposed. The method is based on its catalytic effect on the oxidation of congo red (CR) by potassium bromate in acidic solution. The oxidation reaction is monitored spectrophotometrically by measuring the decrease in the absorbance of CR at a suitable $\lambda_{\max }=570 \mathrm{~nm}$ for the first $10-40 \mathrm{~s}$ from the start of the reaction. Under the optimum experimental conditions (sulfuric acid, $0.3 \mathrm{M} ; \mathrm{CR}, 0.75 \times 10^{-4} \mathrm{M}$; potassium bromate, $5 \times 10^{-4} \mathrm{M}$ and $25^{\circ} \mathrm{C}$ ), nitrite can be determined in the range of $0.015-0.75 \mu \mathrm{g} \mathrm{mL} \mathrm{L}^{-1}$ with the detection limit of $0.006 \mu \mathrm{g} \mathrm{mL}^{-1}$. The relative standard deviation of five replicate determination of $0.25 \mu \mathrm{g} \mathrm{mL}^{-1}$ nitrite was $2.5 \%$. The proposed method was applied satisfactorily to the determination of nitrite in spiked drinking water samples.
\end{abstract}

KEY WORDS: Nitrite, Catalytic effect, Congo red, Spectrophotometry, Drinking water

\section{INTRODUCTION}

Nitrite is a common pollutant of rivers, streams, lakes and water supplies. Anthropogenic sources of nitrite include intensive use of chemical nitrogenous fertilizers, improper disposal of plant and animal waste, municipal and industrial wastewater discharge, sewage disposal systems, landfills [1]. In high doses it induces a state of anoxia in the blood known as 'bluebaby syndrome' or methemoglobinemia and it is also linked with cancer as it can make carcinogenic nitrosamine and $\mathrm{N}$-nitroso compounds. Nitrite ions can be also found in unpolluted waters.

The main sources of nitrite ion in unpolluted surface waters are the processes of organic matter mineralization and nitrification by Nitrosomonas bacteria. The content of nitrite in unpolluted surface and ground water is very low, generally $<0.01-0.02 \mathrm{mg} \mathrm{L}^{-1} \mathrm{NO}_{2}^{-}$[2]. Similar concentrations are typically found in unpolluted seawater. Due to concern about its potential hazards, most international organizations set legal limits to nitrite content in drinking water. The European Union limit for drinking water is $0.1 \mathrm{mg} \mathrm{L}^{-1}$ of $\mathrm{NO}_{2}^{-}-\mathrm{N}$. For this reason, nitrite levels are routinely determined in quality control analyses of drinking, waste, marine and underground waters, among others. This has aroused an interest in developing new analytical methods for determining nitrite in all types of samples.

Due to its potential toxicity, a large number of analytical methods for nitrite have been developed to determine trace amounts of nitrite in water in recent years, including ion chromatography [3-5], polarography [6], voltammetry [7, 8] and flow injection analysis [9-11]. Taking into account that some of the mentioned instrumental methods are too time consuming or require complicated, expensive equipment and lack of sensitivity, the most important methods for determination of nitrites are colorimetric ones.

The most common choice for this purpose is the spectrophotometric method based on the Griess reaction [12], which consists in the formation of a strongly colored azo dye. Thus, an

*Corresponding author. E-mail: z_moldovan@yahoo.com 
amine (namely, sulfanilamide) is diazotized by means of nitrite under special conditions (in acidic media) to form a transient diazonium salt. This intermediate is then allowed to react with a coupling reagent, namely naphtyl-1-amine, to form a deep red-colored azo dye. This procedure has been the subject of several modifications [13-16]. However, many of the modified methods are subjected of several drawbacks (azo dye formation is dependent on $\mathrm{pH}$, diazotization temperature and coupling time; toxicity of certain amines are also an important point for chemists). As examples, the reaction system $p$-nitroaniline + diphenylamine is time consuming and less sensitive [13]; the system 4-(1-metyl-1-mesitylcyclobutan-3-yl)-2-aminothiazole $+N, N$ dimethyl aniline is $\mathrm{pH}$-dependent, time consuming and extractive [14]; by using $p$-nitroaniline + 2-methyl-8-quinolinol, most cations and anions interfered [15]; the reaction system $p$ aminophenylmercaptoacetic acid $+N$-(1-naphthyl)ethylenediamine dihydrochloride is time consuming [16]. Besides, these procedures involve the use of carcinogenic reagents, which makes them outside of the standards of clean chemistry [17]. In order to attain these standards, alternative spectrophotometric reagents, from two classes of compounds, namely phenoxazines and sulphonamides have also been used for the same purpose [18].

Indirect spectrophotometric methods for the determination of nitrite based on the study of decrease in the absorbance of the dye have been reported. Several of these methods for nitrite determination are based on its catalytic action on the oxidation of some organic reagents with suitable oxidizing agents. In most cases, the following classes of organic reagents were used: fuchsin compounds (bromocresol purple [19]; catechol violet [20]; thymol blue [21]; methylthymol blue [22]); fuchson-imines (crystal violet [23]; methyl violet [24]; brilliant green [25]); phenoxazine dyes (brilliant cresyl blue [26]; gallocyanine [27]); pyridylhydrazone derivatives [28]); substituted phenothiazine derivatives (thionine [29]; chlorpromazine [30]; prochlorperazine [31]; perphenazine [32]); triarylmethane derivatives - fluorescein analogues (bromopyrogallol red [33]). A few works propose the use of azo dyes (methyl red [34]; 2-(4chloro-2-phosphonophenylazo)-7-(4-nitrophenylazo)-1,8-dihydroxynaphthalene-3,6-disulfonic acid [35]). Kinetic-spectrophotometric methods for nitrite analysis present some advantages such as high sensitivity, low detection limits, good selectivity, rapid analysis and inexpensive instrumentation.

The current paper describes another kinetic spectrophotometric method for determination of nitrite based on its effect on the redox reaction between an azo dye, namely congo red and bromate. For this purpose, a simple and efficient way for predicting the optimum working conditions was proposed.

\section{EXPERIMENTAL}

\section{Chemicals and apparatus}

All chemicals were of analytical reagent grade and were purchased from Merck (Darmstadt, Germany). Deionized-distilled water was used throughout. A stock standard nitrite solution $\left(1000 \mu \mathrm{g} \mathrm{mL}^{-1}\right)$ was prepared by dissolving $150 \mathrm{mg}$ of pre-dried sodium nitrite in water containing a small amount of $\mathrm{NaOH}$ to prevent its decomposition. The resulting solution was diluted in a $100 \mathrm{~mL}$ volumetric flask after adding $0.2 \mathrm{~mL}$ of chloroform as a stabilizer, to prevent bacterial growth. This solution was stored in a brown bottle and kept at $4{ }^{\circ} \mathrm{C}$; it was used within two weeks of preparation. A stock solution of $5 \times 10^{-4} \mathrm{M}$ congo red was prepared by dissolving $\mathrm{CR}$ and then diluting to the mark with deionized-distilled water in a $100 \mathrm{~mL}$ volumetric flask wrapped with an aluminum foil and kept at $4{ }^{\circ} \mathrm{C}$, when not in use. The solution was stable for at least 2-months. A $4 \mathrm{M}$ solution of sulfuric acid was prepared by diluting concentrated sulfuric acid with water. A $0.1 \mathrm{M}$ potassium bromate was prepared in deionizeddistilled water. Stock solutions $(1000 \mu \mathrm{g} / \mathrm{mL})$ of interfering ions were also prepared by 
dissolving suitable salts in water or hydrochloric acid solution. Required working standard solutions were prepared by diluting the corresponding stock solutions.

Absorbance measurements were performed on a UV-VIS spectrophotometer (V-530 JascoJapan) equipped with cells holder thermostated by an external circulating water bath. Quartz cells of $1-\mathrm{cm}$ path length were used.

The temperature was kept constant at $25 \pm 0.1{ }^{\circ} \mathrm{C}$ by using the thermostated water bath, GFL 1003 type (Burgwedal, Germany), with an accuracy of $\pm 0.1^{\circ} \mathrm{C}$. Eppendorf vary-pipettes (10$100 ; 100-1000$ and $500-2500 \mu \mathrm{L}$ ) were used to deliver accurate volumes.

\section{General procedure}

The working solutions, sample solutions and pure water were kept at $25{ }^{\circ} \mathrm{C}$ in the thermostated water-bath for at least $15 \mathrm{~min}$ to attain the equilibrium temperature. An aliquot of standard stock solution equivalent to $0.01-1.75 \mu \mathrm{g} \mathrm{mL}^{-1}$ nitrite, $0.3 \mathrm{~mL}$ of $\mathrm{RC}$ solution $5 \times 10^{-4} \mathrm{M}, 0.2 \mathrm{~mL}$ of $\mathrm{H}_{2} \mathrm{SO}_{4}$ solution $3 \mathrm{M}$ were transferred into a quartz cell. Deionized-distilled water was added to make the volume to $2.02 \mathrm{~mL}$ as soon as $20 \mu \mathrm{L}$ of $\mathrm{KBrO}_{3} 5 \times 10^{-2} \mathrm{M}$ was added. Then, the cuvette was covered with lid; after that the solution was quickly shaken and placed in the spectrophotometer cell holder using exactly time $10 \mathrm{~s}$. The redox reaction was traced spectrophotometrically by monitoring the decrease in absorbance of CR with time from 10 to 40 $\mathrm{s}$ at $\lambda_{\max }=570 \mathrm{~nm}$ (allowing a lag time of $5 \mathrm{~s}$ ) against water as reference. The discoloration rate of CR was calculated from the slope of the linear part of the $A$ (at $\lambda_{\max }=570 \mathrm{~nm}$ ) $-t$ curve, within $30 \mathrm{~s}$, by applying the formula: $R=\Delta A_{10-40 s} / \Delta t$, where $R=$ discoloration rate of $\mathrm{CR}$, expressed in absorbance units (a.u.) $\times \min ^{-1} . \Delta A_{10-40 \mathrm{~s}}=A_{10 \mathrm{~s}}-A_{40 \mathrm{~s}}$, where $A_{10 \mathrm{~s}}$ is the absorbance of $\mathrm{CR}$, at $t_{1}=10 \mathrm{~s}$ and $A_{40 \mathrm{~s}}$ is the absorbance of CR at $t_{2}=40 \mathrm{~s} ; \Delta t=t_{2}-t_{1}=30 \mathrm{~s}=0.5 \mathrm{~min}$. Blank experiments were also performed by adding deionized-distilled water instead of the standard nitrite solution. The initial rates of catalyzed reactions were calculated by subtracting the rate corresponding to blank solutions containing no nitrite. Under optimum working conditions, a calibration curve was constructed by plotting the difference between the discoloration rates of $\mathrm{CR}$ in the absence and in the presence of nitrite, as a function of nitrite concentration.

To optimize the working parameters, $1 \mathrm{~mL}$ of the standard solution containing $0.5 \mu \mathrm{g}$ of nitrite was directly pipetted into a glass cuvette, followed by addition of aliquots of congo red and $\mathrm{H}_{2} \mathrm{SO}_{4}$ solutions having different concentrations. Deionized-distilled water was added to make the volume to $2.02 \mathrm{~mL}$ as soon as $20 \mu \mathrm{L}$ of $\mathrm{KBrO}_{3}$ was added. Then, the general procedure was applied. The dependence of reagents concentrations on the rate of catalyzed oxidation of $\mathrm{CR}$ was studied in the following ranges: $[\mathrm{CR}]=0.25 \times 10^{-4} \mathrm{M}-1 \times 10^{-4} \mathrm{M},\left[\mathrm{BrO}_{3}{ }^{-}\right]=$ $1 \times 10^{-4} \mathrm{M}-10 \times 10^{-4} \mathrm{M},\left[\mathrm{H}_{2} \mathrm{SO}_{4}\right]=0.2-0.5 \mathrm{M}$.

The nitrite content of the synthetic or real samples was determined from the calibration curve; the mentioned samples were prepared according to the general procedure.

\section{Procedure for recovery tests}

The validity of the proposed method was performed by recovery studies using the standard addition method. For this purpose, known amounts of standard nitrite were spiked to real samples and the total amount of the analyte was estimated by applying the proposed procedure.

\section{Procedure for studying the influence of foreign ions}

An aliquot of standard stock solution equivalent to $0.25 \mu \mathrm{g} \mathrm{mL}^{-1}$ nitrite, $0.3 \mathrm{~mL}$ of $\mathrm{CR}$ solution $5 \times 10^{-4} \mathrm{M}, 0.2 \mathrm{~mL}$ of $\mathrm{H}_{2} \mathrm{SO}_{4}$ solution $3 \mathrm{M}$ and an aliquot of a possible interfering ion (with known concentration) were transferred into a quartz cell. Deionized-distilled water was added to 
make the volume to $2.02 \mathrm{~mL}$ as soon as $20 \mu \mathrm{L}$ of $\mathrm{KBrO}_{3} 5 \times 10^{-2} \mathrm{M}$ was added. Then, the general procedure was applied.

\section{RESULTS AND DISCUSSION}

Reaction between congo red ((1-naphthalenesulfonic acid, 3,3'-[(1,1'-biphenyl]-4,4'-diy]bis(azo)]bis(4-amino-), disodium salt)) and bromate in acid medium takes place very slowly which is confirmed by the gradual diminution of absorbance. When the nitrite ion catalyzes this reaction, the oxidation of $\mathrm{CR}$ is much faster, resulting in a considerable discoloration of mixture (Figure 1). For the oxidation of organic compounds (OC), the following reactions can describe the role of nitrite as a catalyst in the presence of bromate [36]:

$$
\begin{aligned}
& 10 \mathrm{NO}_{2}^{-}+2 \mathrm{BrO}_{3}^{-}+12 \mathrm{H}^{+} \rightarrow 5 \mathrm{~N}_{2} \mathrm{O}_{4}+\mathrm{Br}_{2}+6 \mathrm{H}_{2} \mathrm{O} \\
& (\mathrm{OC})_{\mathrm{red}}+\mathrm{N}_{2} \mathrm{O}_{4} \rightarrow(\mathrm{OC})_{\mathrm{ox}}+2 \mathrm{NO}_{2}^{-}+2 \mathrm{H}^{+}
\end{aligned}
$$

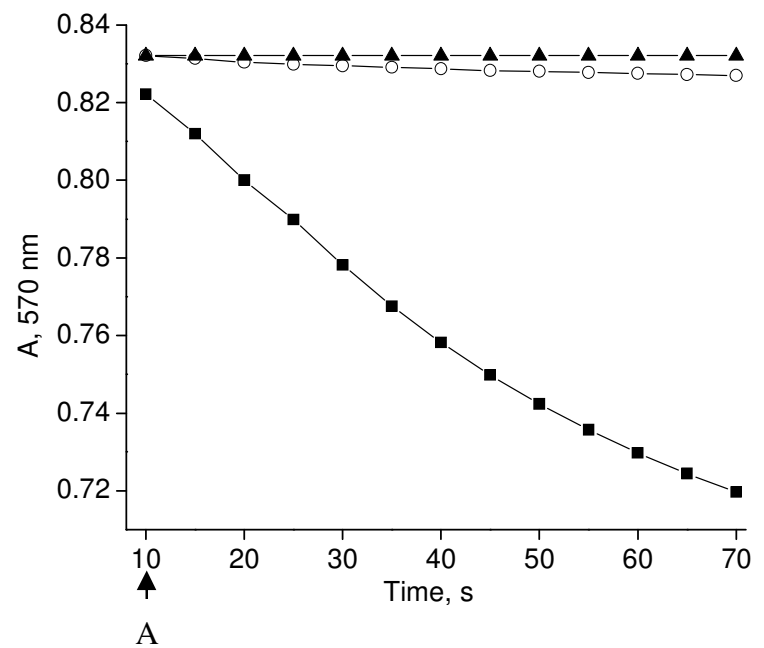

Figure 1. Variation of CR absorbance with time: $(\boldsymbol{\Delta}) \mathrm{NO}_{2}^{-}+\mathrm{CR}+\mathrm{H}_{2} \mathrm{SO}_{4}$; (

$$
\begin{aligned}
& \mathrm{BrO}_{3}^{-} ;(\mathbf{\Xi}) \mathrm{NO}_{2}^{-}+\mathrm{CR}+\mathrm{H}_{2} \mathrm{SO}_{4}+\mathrm{BrO}_{3}^{-} .\left[\mathrm{NO}_{2}^{-}\right]=0.25 \mu \mathrm{g} \mathrm{mL}{ }^{-1} ;[\mathrm{CR}]=0.75 \times 10^{-4} \mathrm{M} ; \\
& {\left[\mathrm{H}_{2} \mathrm{SO}_{4}\right]=0.3 \mathrm{M} ;\left[\mathrm{BrO}_{3}^{-}\right]=5 \times 10^{-4} \mathrm{M} .}
\end{aligned}
$$

After scanning the spectrum of CR in acid medium, in the wavelength range 450-650 nm, the wavelength of maximum absorbance attributed to CR was found to be $\lambda_{\max }=570 \mathrm{~nm}$. Preliminary experiments showed that the position of the CR characteristic band does not change with varying the acidity and reagent's concentrations. To arrive at the optimum working conditions, the main parameters that can influence the performance of the proposed method were studied. The discoloration rate values were calculated as difference between the rates of catalyzed and non-catalyzed reactions, performed in the same experimental conditions. Because of the sensitivity and the length of the time required to determine the amounts of nitrite, $0.5 \mathrm{~min}$ was selected as the reaction time for the procedure. 


\section{Optimization of working parameters}

In order to optimize the working parameters, preliminary experiments were made as follows: at different level of bromate concentration $\left(10^{-4} ; 5 \times 10^{-4}\right.$ and $\left.10^{-3} \mathrm{M}\right)$, the concentrations $\mathrm{H}_{2} \mathrm{SO}_{4}$ and $\mathrm{CR}$ were varied in the following ranges: $0.2-0.5 \mathrm{M} \mathrm{H}_{2} \mathrm{SO}_{4}$ and $0.25 \times 10^{-4}-1 \times 10^{-4} \mathrm{M} \mathrm{CR}$. The effect of these parameters on the redox reaction between $\mathrm{CR}$ and bromate, in the presence of $0.25 \mu \mathrm{g} \mathrm{mL}^{-1} \mathrm{NO}_{2}^{-}$, is illustrated in Figure 2. By using $10^{-3} \mathrm{M} \mathrm{BrO}_{3}^{-}$or $5 \times 10^{-4} \mathrm{M}_{\text {bromate the }}$ discoloration rate of $\mathrm{CR}$ decreases with the increasing concentration of sulfuric acid and $\mathrm{CR}$ (Figures $2 \mathrm{a}$ and $2 \mathrm{~b}$ ). In presence of $10^{-4} \mathrm{M} \mathrm{BrO}_{3}^{-}$, the values of initial rate were insignificant, with an increasing trend with increasing concentration of sulfuric acid and reaching the maximum value in presence of $0.25 \times 10^{-4} \mathrm{M}$ CR (Figure 2c).

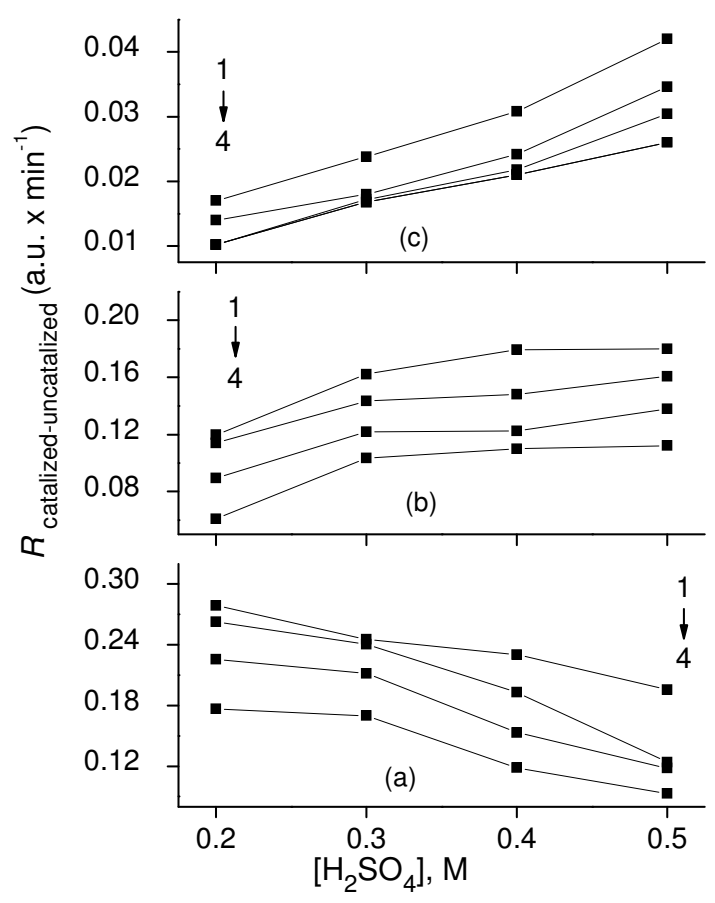

Figure 2. Discoloration rate dependence on sulfuric acid and $\mathrm{CR}$ concentration at different concentration of bromate and $\mathrm{CR}$. $\left[\mathrm{NO}_{2}^{-}\right]=0.25 \mu \mathrm{g} \mathrm{mL}^{-1}$; $\left[\mathrm{BrO}_{3}^{-}\right], \mathrm{M}$ : (a) $10^{-3}$; (b) $5 \times 10^{-4}$; (c) $10^{-4}$; [CR] $\times 10^{4}$, M: (1) 0.25 ; (2) 0.50 ; (3) 0.75 ; (4) 1.00 .

The next step was to select the optimum working mixture between those prepared in presence of $10^{-3}$ and $5 \times 10^{-4} \mathrm{M} \mathrm{BrO}_{3}^{-}$. Usually, the value of each parameter influencing the discoloration rate is optimal when the rate reaction reaches the maximum value. The experimental data have not confirmed this rule. This because, in some cases, a maximum value of discoloration rate is not accompanied by a linear decrease of the absorbance of the organic reagent (congo red) with time. As consequence, in such cases, the linear dependence of the analytical signal (the rate reaction) on the nitrite concentration is valuable for a close range of this concentration. Moreover, a poor linearity results in poor precision. Taking into account this behavior, the linear trend line was added to each recorded $A-t$ curve and the corresponding 
squared correlation coefficient $r^{2}$ was calculated (Table 1). In the following working conditions: $[\mathrm{CR}]=0.25 \times 10^{-4} \mathrm{M}-1 \times 10^{-4} \mathrm{M} ;\left[\mathrm{H}_{2} \mathrm{SO}_{4}\right]=0.4-0.5 \mathrm{M}$ and $\left[\mathrm{KBrO}_{3}\right]=10^{-3} \mathrm{M}$, the linear part of $A-t$ curves is considerable shortened to values which reaches $10-20 \mathrm{~s}$, behavior confirmed by means of the corresponding $r^{2}$ values (less than 0.84 ). In the mentioned conditions, a significant increase in the discoloration rate takes place. As consequence, a quick decrease of the absorbance of CR takes place. It was found that the best linear correlation between the decrease of absorbance and time, confirmed by the best value of $r^{2}(>0.997)$, take place in the following working conditions, used for further experiments: $\left[\mathrm{H}_{2} \mathrm{SO}_{4}\right]=0.3 \mathrm{M}$; $\left[\mathrm{KBrO}_{3}\right]=5 \times 10^{-4} \mathrm{M}$; $[\mathrm{CR}]$ $=0.75 \times 10^{-4} \mathrm{M}$. Based on the optimum values of the experimental data one can assume the follows. The decrease in rate at sulfuric acid concentration higher that $0.3 \mathrm{M}$ may be attributed to protonation of $\mathrm{CR}$, which might stop oxidation or make oxidation quite difficult to occur. The optimum value of CR concentration $\left(0.75 \times 10^{-4} \mathrm{M}\right)$ is in accordance to the linearity of $A_{570 \mathrm{~nm}}$ [CR] curve, valid up to $0.75 \times 10^{-4} \mathrm{M}$. A $5 \times 10^{-4} \mathrm{M} \mathrm{BrO}_{3}^{-}$was used in the recommended procedure. Larger amounts of bromate cause decreases in the sensitivity. This effect is because at higher concentration of bromate, the rate of the blank reaction is very fast, and thus a diminution of the net reaction rate signal takes place.

Table 1. Squared correlation coefficient of $A-t$ curves.

\begin{tabular}{|c|c|c|c|c|c|}
\hline $\begin{array}{c}{\left[\mathrm{BrO}_{3}{ }^{-}\right],} \\
M\end{array}$ & {$\left[\mathrm{H}_{2} \mathrm{SO}_{4}\right], \mathrm{M}$} & \multicolumn{3}{|c|}{ Squared correlation coefficient, $r^{2}$} \\
\cline { 2 - 6 } & & $(\mathrm{a})^{*}$ & $(\mathrm{~b})^{*}$ & $(\mathrm{c})^{*}$ & $(\mathrm{~d})^{*}$ \\
\hline \multirow{3}{*}{0005} & 0.2 & 0.9903 & 0.9907 & 0.9901 & 0.9874 \\
\cline { 2 - 6 } & 0.3 & 0.9945 & 0.9954 & 0.9976 & 0.997 \\
\cline { 2 - 6 } & 0.4 & 0.9734 & 0.9772 & 0.9966 & 0.9915 \\
\cline { 2 - 6 } & 0.5 & 0.962 & 0.9708 & 0.9796 & 0.9796 \\
\hline \multirow{3}{*}{001} & 0.2 & 0.9879 & 0.9794 & 0.9697 & 0.9569 \\
\cline { 2 - 6 } & 0.3 & 0.9901 & 0.9361 & 0.9238 & 0.9067 \\
\cline { 2 - 6 } & 0.4 & 0.8000 & 0.7601 & 0.7742 & 0.8392 \\
\cline { 2 - 6 } & 0.5 & 0.7170 & 0.6428 & 0.7677 & 0.8155 \\
\hline
\end{tabular}

* Concentration of congo red, [CR] $\times 10^{4}$, M: (a) 0.25 ; (b) 0.5 ; (c) 0.75 ; (d) 1 .

Effect of the ionic strength

The effect of the ionic strength on the catalyzed reaction was studied in the presence of $\mathrm{NaNO}_{3}$ solutions. As shown in Figure 3, the reaction rate of CR was independent of the ionic strength up to $0.05 \mathrm{M} \mathrm{NaNO}_{3}$. The effect of $\mathrm{NaNO}_{3}$ on the redox reaction between $\mathrm{CR}$ and bromate in presence of nitrite ions can be explained by considering the reaction on a microscopic scale. The solution in which equilibrium is established contains a variety of cations and anions such as $\mathrm{Na}^{+}, \mathrm{H}_{3} \mathrm{O}^{+}, \mathrm{BrO}_{3}^{-}, \mathrm{NO}_{2}^{-}$, and $\mathrm{NO}_{3}^{-}$. Thus, these species are surrounded by charged ionic atmospheres, which partially screen the ions from each other. The redox reaction between $\mathrm{CR}$ and bromate in presence of nitrite requires the disruption of the ionic atmospheres surrounding the mentioned ions. Increasing the concentrations of ions in solution (by adding $\mathrm{NaNO}_{3}$ ), increases the size of these ionic atmospheres. Since more energy is now required to disrupt the ionic atmospheres, there is a decrease in the formation of reaction products, and an apparent increase in the equilibrium constant [37].

\section{Order of addition of reactants}

It was observed that the order of addition of reactants can influence the rate of the oxidation process. Thus, sequence (1) nitrite-CR-sulfuric acid-bromate gave the highest value of oxidation 
rate while sequence (5) bromate-sulfuric acid-nitrite-CR gave the lowest value of oxidation rate. This behavior could be explained as follows: by adding bromate and nitrite before CR \{sequences (3) and (4)\}, a partial oxidation of nitrite could take place [32]. Moreover, this process is favored and accentuated by the addition of nitrite to the acidified bromate solution (sequence (5)) [32]. On the basis of the oxidation rates illustrated in Figure 4, sequence (1) was chosen to be applied in the proposed method. The performances of the proposed method were verified on samples having the following composition and respecting this order of reagents addition: $1-\mathrm{mL}$ sample solution containing a known amount of nitrite $+0.3 \mathrm{~mL}$ of $5 \times 10^{-4} \mathrm{M} \mathrm{CR}$ $+0.2 \mathrm{~mL}$ of $3 \mathrm{M} \mathrm{H}_{2} \mathrm{SO}_{4}+0.5 \mathrm{~mL}$ of deionized distilled water $+20 \mu \mathrm{L}$ of $5 \times 10^{-2} \mathrm{M}$ bromate.

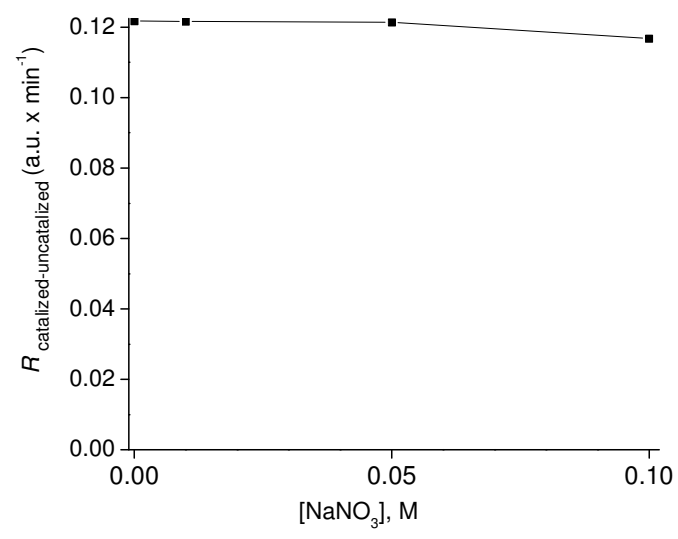

Figure 3. Discoloration rate dependence on sodium nitrate concentration. $\left[\mathrm{NO}_{2}{ }^{-}\right]=0.25 \mu \mathrm{g} \mathrm{mL}{ }^{-1}$; $[\mathrm{CR}]=0.75 \times 10^{-4} \mathrm{M} ;\left[\mathrm{H}_{2} \mathrm{SO}_{4}\right]=0.3 \mathrm{M} ;\left[\mathrm{BrO}_{3}^{-}\right]=5 \times 10^{-4} \mathrm{M}$.

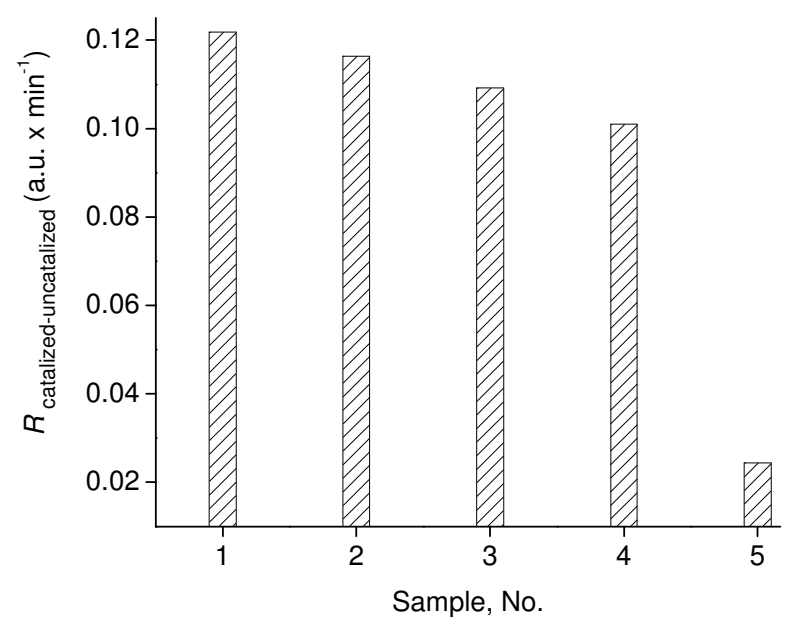

Figure 4. Discoloration rate variation with reactants addition order. $\left[\mathrm{NO}_{2}^{-}\right]=0.25 \mu \mathrm{g} \mathrm{mL}^{-1}$; [CR] $=0.75 \times 10^{-4} \mathrm{M} ;\left[\mathrm{H}_{2} \mathrm{SO}_{4}\right]=0.3 \mathrm{M} ;\left[\mathrm{BrO}_{3}^{-}\right]=5 \times 10^{-4} \mathrm{M}$. (1) $\mathrm{NO}_{2}^{-}-\mathrm{CR}-\mathrm{H}_{2} \mathrm{SO}_{4}-\mathrm{BrO}_{3}^{-}$; (2) $\mathrm{BrO}_{3}{ }^{-} \mathrm{CR}-\mathrm{H}_{2} \mathrm{SO}_{4}-\mathrm{NO}_{2}{ }^{-}$; (3) $\mathrm{CR}-\mathrm{H}_{2} \mathrm{SO}_{4}-\mathrm{NO}_{2}{ }^{-}-\mathrm{BrO}_{3}{ }^{-}$; (4) $\mathrm{BrO}_{3}{ }^{-}-\mathrm{NO}_{2}{ }^{-}-\mathrm{CR}^{-}-\mathrm{H}_{2} \mathrm{SO}_{4}$ (5) $\mathrm{BrO}_{3}^{-}-\mathrm{H}_{2} \mathrm{SO}_{4}^{-} \mathrm{NO}_{2}^{-} \mathrm{CR}$.

Bull. Chem. Soc. Ethiop. 2012, 26(2) 


\section{Analytical figures of merit}

Once the optimum working conditions were established, the proposed spectrophotometric method was evaluated with respect to linearity, LOD, LOQ, accuracy, precision.

A calibration curve was obtained by applying the fixed time method under the optimum conditions of $10-40 \mathrm{~s}$ from the initiation of the reaction at $25^{\circ} \mathrm{C}$ with the optimum concentration of reagents. This interval time was selected due to the good correlation obtained. The calibration curve was plotted by the use of absorbance values obtained from five replicate samples of same nitrite content. The calibration curve was linear in the concentration range $0.015-0.75 \mu \mathrm{g} \mathrm{mL}^{-1}$ of nitrite; the linear regression equation is:

$$
R=\Delta[\mathrm{CR}] / \Delta \mathrm{d} t=0.4857\left[\mathrm{NO}_{2}\right]+0.0014
$$

where $\left[\mathrm{NO}_{2}{ }^{-}\right]$is the nitrite concentration expressed in $\mu \mathrm{g} \mathrm{mL}{ }^{-1}$; the squared correlation coefficient, $r^{2}=0.9986$; the detection limit, LOD (calculated as three times the standard deviation of the blank) $=0.006 \mu \mathrm{g} \mathrm{mL}^{-1} \mathrm{NO}_{2}^{-}$and $\mathrm{LOQ}=0.015 \mu \mathrm{g} \mathrm{mL}^{-1} \mathrm{NO}_{2}^{-}$. LOQ represents the lowest calibration standard. In order to estimate the accuracy and precision of the proposed method, standard solutions of $0.10 ; 0.25$ and $0.50 \mu \mathrm{g} \mathrm{mL}^{-1}$ nitrite were analyzed according to the recommended procedure. For this purpose, five replicate determinations of each concentration were prepared. As it is seen in Table 2, relative standard deviations ranged from $2.5 \%$ to $3.6 \%$ and the percent recovery from $99.7 \%$ to $101.2 \%$. The results in Table 2 were obtained by performing the experiments on samples with the following composition: 1-mL sample solution containing the nitrite ion at different concentration level $+0.3 \mathrm{~mL}$ of $5 \times 10^{-4} \mathrm{M} \mathrm{CR}+0.2 \mathrm{~mL}$ of $3 \mathrm{M} \mathrm{H}_{2} \mathrm{SO}_{4}+0.5 \mathrm{~mL}$ of deionized-distilled water $+20 \mu \mathrm{L}$ of $5 \times 10^{-2} \mathrm{M}$ bromate.

Table 2. Precision and accuracy of the proposed method.

\begin{tabular}{|c|c|c|c|}
\hline \multicolumn{2}{|c|}{ Nitrite, $\mu \mathrm{g} \mathrm{mL}{ }^{-1}$} & $R S D$ & $R$ \\
\cline { 1 - 2 } Taken & ${ }^{\mathrm{a}}$ Found $\pm t S N^{-0.5}$ & & \\
\hline 0.100 & $0.101 \pm 0.005$ & 3.61 & 101.16 \\
\hline 0.250 & $0.253 \pm 0.008$ & 2.49 & 101.08 \\
\hline 0.500 & $0.499 \pm 0.018$ & 3.07 & 99.73 \\
\hline
\end{tabular}

${ }^{a}$ Mean $\pm 95 \%$ confidence limit, for $N=5 ; t=2.77=t$-distribution for confidence level of $95 \%$ with $N$ - 1 degrees of freedom. $R S D=$ relative standard deviation; $R=$ percent recovery.

\section{Effect of diverse ions}

To evaluate the selectivity of the proposed method, the effect of foreign ions on the determination of nitrite was studied by adding known quantities of each ion to a solution containing $0.5 \mu \mathrm{g}$ nitrite (final volume $=2.02 \mathrm{~mL}$ ) and determining the nitrite by the proposed method. The tolerance limits of foreign ions, taken as the concentrations $\left(\mu \mathrm{g} \mathrm{mL}^{-1}\right)$ which cause errors less than 3\% are given in Table 3. These results clearly show that most of the ions, which are normally associated with nitrite in drinking water samples do not interfere. However, $\mathrm{Hg}(\mathrm{II})$, $\mathrm{Ag}(\mathrm{I}), \mathrm{Br}^{-}$and $\mathrm{S}^{2-}$ have lowest tolerance limits. The majority of foreign ions mentioned in Table 3 are present in drinking water at much lower concentration limits. Hence, the proposed method could be applied for the determination of nitrite in water samples for their quality control.

Taking into account that some brends of bottled drinking water have high calcium and magnesium content, in such cases, the proposed method for nitrite determination involves as a preliminary step the retention of these cations on Dowex 50W-X8 resin in its $\mathrm{NH}_{4}{ }^{+}$form (Dow Chemical Co., Midland, Mich.). For this purpose a fixed volume of the water sample $(10 \mathrm{~mL})$ 
was put over a weighted portion of the dry resin $(0.5 \mathrm{~g})$. The mixture was stirred for $30 \mathrm{~min}$. Then, an aliquot of the supernatant solution was used for nitrite determination. After this pretreatment, the tolerance limits of $\mathrm{Ca}^{2+}$ and $\mathrm{Mg}^{2+}$ were raised to $500 \mu \mathrm{g} \mathrm{mL}^{-1}$.

Table 3. Influence of foreign ions on the determination of nitrite $\left(0.25 \mu \mathrm{g} \mathrm{mL}^{-1}\right)$.

\begin{tabular}{|c|c|}
\hline Foreign ions & Tolerance limit, $\mu \mathrm{g} \mathrm{mL}^{-1}$ \\
\hline $\begin{array}{l}\mathrm{NH}_{4}^{+}, \mathrm{Na}^{+}, \mathrm{K}^{+}, \mathrm{Zn}^{2+}, \mathrm{Ni}^{2+}, \mathrm{Co}^{2+}, \mathrm{CH}_{3} \mathrm{COO}^{-}, \mathrm{NO}_{3}^{-}, \mathrm{PO}_{4}^{3-}, \\
\mathrm{CO}_{3}{ }^{2-}, \mathrm{SO}_{4}{ }^{2-}, \mathrm{C}_{2} \mathrm{O}_{4}{ }^{2-}\end{array}$ & 500 \\
\hline $\mathrm{Ca}^{2+}, \mathrm{Mg}^{2+}$ & 150 \\
\hline${ }^{\mathrm{a}} \mathrm{Ca}^{2+},{ }^{\mathrm{a}} \mathrm{Mg}^{2+}$ & 500 \\
\hline $\mathrm{Al}^{3+}, \mathrm{Cu}^{2+}$ & 150 \\
\hline $\mathrm{Fe}^{3+}, \mathrm{Mn}^{2+}$ & 50 \\
\hline $\mathrm{Cl}^{-}$ & 300 \\
\hline $\mathrm{Cr}^{3+}$ & 30 \\
\hline $\mathrm{C}_{4} \mathrm{H}_{4} \mathrm{O}_{6}{ }^{2-}$ & 20 \\
\hline $\mathrm{Pb}^{2+}, \mathrm{Fe}^{2+}, \mathrm{V}^{4+}, \mathrm{I}^{-}$ & 2.5 \\
\hline $\mathrm{Ag}^{+}$ & 0.3 \\
\hline $\mathrm{Hg}^{2+}, \mathrm{Br}^{-}$ & 0.15 \\
\hline $\mathrm{S}^{2-}$ & 0.01 \\
\hline
\end{tabular}

${ }^{*}$ After retention on Dowex 50WX80 (ammonium form).

\section{Application of the Method}

The analytical potential of the method was tested by applying it to the determination of spiked amounts of nitrite in drinking water samples collected and bottled in different places of Romania. The samples of potable water were collected from packaged water bottles. To a fixed volume of the water sample, nitrite at two levels was added, and the total was found by the proposed methods. Each test was repeated four times. The results presented in Table 4 show that the recoveries were in the range $98.33-99.69 \%$ indicating that common constituents normally encountered in drinking water samples, did not interfere in the determination. Thus, accuracy and reliability of the methods were further ascertained by performing these recovery experiments.

Table 4. Recovery data for drinking water samples spiked with nitrite.

\begin{tabular}{|c|c|c|c|}
\hline \multirow{2}{*}{ Mineral water } & \multicolumn{2}{|c|}{ Nitrite, $\mu \mathrm{g} \mathrm{mL}^{-1}$} & \multirow{2}{*}{$R, \%$} \\
\hline & Add & ${ }^{\mathrm{a}}$ Found $\pm \mathrm{tSN}^{-0.5}$ & \\
\hline $\begin{array}{l}\text { Borsec } \\
\text { (source: Borsec-Faget) }^{\mathrm{b}}\end{array}$ & $\begin{array}{l}0.250 \\
0.500\end{array}$ & $\begin{array}{l}0.246 \pm 0.009 \\
0.493 \pm 0.007\end{array}$ & $\begin{array}{l}98.33 \\
98.51\end{array}$ \\
\hline $\begin{array}{l}\text { Perla Harghitei } \\
\text { (source: Sâncrăieni-Harghita) }\end{array}$ & $\begin{array}{l}0.250 \\
0.500\end{array}$ & $\begin{array}{l}0.247 \pm 0.005 \\
0.493 \pm 0.007\end{array}$ & $\begin{array}{l}98.99 \\
98.69\end{array}$ \\
\hline $\begin{array}{l}\text { Wonder Spring } \\
\text { (source: Stâna de Vale) }^{\mathrm{d}}\end{array}$ & $\begin{array}{l}0.250 \\
0.500\end{array}$ & $\begin{array}{l}0.249 \pm 0.006 \\
0.497 \pm 0.016\end{array}$ & $\begin{array}{l}99.69 \\
99.37\end{array}$ \\
\hline
\end{tabular}

${ }^{\text {a } M e a n} \pm 95 \%$ confidence limit, for $N=4 ; t=3.18=t$-distribution for confidence level of $95 \%$ with $N$ - 1 degrees of freedom. ${ }^{\mathrm{b}}$ Certified composition $\left(\mu \mathrm{g} \mathrm{mL}^{-1}\right): \mathrm{Na}^{+}, 70.6 ; \mathrm{K}^{+}, 9.72 ; \mathrm{Mg}^{2+}, 43.8 ; \mathrm{Ca}^{2+}, 107.12 ; \mathrm{Cl}^{-}, 16 ; \mathrm{SO}_{4}{ }^{2-}, 3.3$.

${ }^{\mathrm{c}}$ Certified composition $\left(\mu \mathrm{g} \mathrm{mL}{ }^{-1}\right): \mathrm{Na}^{+}, 2.80 ; \mathrm{Mg}^{2+}, 39.6 ; \mathrm{Ca}^{2+}, 57.35 .{ }^{d}$ Certified composition $\left(\mu \mathrm{g} \mathrm{mL}^{-1}\right): \mathrm{Na}^{+}$, $1.20 ; \mathrm{K}^{+}, 0.7 ; \mathrm{Mg}^{2+}, 4.70 ; \mathrm{Ca}^{2+}, 15.31$. 


\section{CONCLUSIONS}

The CR-bromate-acid system, proposed in the present paper, could be used successfully for the quantitative determination of nitrite in drinking water samples. The proposed method is inexpensive, fairly rapid and sensitive. The method has added advantages over other reported methods, owing to its sensitivity, low detection limit, time of the analytical signal (Table 5). The proposed method can be used as an alternative to other reported kinetic-spectrophotometric methods and as a cheaper and simple instrument for quality control of drinking water samples.

Table 5. Comparison of dynamic range and detection limit of the present work with previously reported results.

\begin{tabular}{|l|c|c|c|c|}
\hline Reaction system & $\begin{array}{c}\text { Dynamic } \\
\text { range, } \\
\text { ng mL }\end{array}$ & $\begin{array}{c}\text { Detection } \\
\text { limit, } \\
\mathrm{ng} \mathrm{mL}^{-1}\end{array}$ & $\begin{array}{c}\text { Time, } \\
\mathrm{s}\end{array}$ & Ref. \\
\hline Bromcresol Purple - Bromate & $10-400$ & 9 & 720 & {$[19]$} \\
\hline Catechol Violet - Bromate & $20-350$ & - & - & {$[20]$} \\
\hline Thymol Blue - Bromate & $5-80$ & 4.5 & - & {$[21]$} \\
\hline Crystal Violet - Bromate & $1-50$ & 0.3 & $32 / \mathrm{h}$ & {$[23]$} \\
\hline Brilliant Green - Bromate & $20-350$ & - & - & {$[25]$} \\
\hline Brilliant Cresyl Blue - Bromate & $0.5-1000$ & - & - & {$[26]$} \\
\hline Gallocyanine - Bromate & $20-500$ & 10 & $30 \pm 5 / \mathrm{h}$ & {$[27]$} \\
\hline Bromopyrogallol Red - Bromate & $200-1000$ & - & - & {$[33]$} \\
\hline Methyl Red - Bromate & $50-1200$ & 45 & 50 & {$[34]$} \\
\hline Chlorophosphonazo- $p \mathrm{~N}-$ Bromate & $50-1000$ & 18 & 30 & {$[35]$} \\
\hline Congo Red - Bromate & $15-750$ & 6 & 30 & This work \\
\hline
\end{tabular}

\section{REFERENCES}

1. Nollet, L.M.L. Handbook of Water Analysis, CRC Press: New York; 2000; p 201.

2. Radojević, M.; Bashkin, V.N. Practical Environmental Analysis, Royal Society of Chemistry: Great Britain; 1999; p 220.

3. Stefanovic, S.C.; Bolanca, T.; Curkovic, L. J. Chromatogr. A 2001, 18, 325.

4. Rantakokko, P.; Mustonen, S.; Yritys, M.; Vartiainen, T. J. Liq. Chromatogr. 2004, 27, 829.

5. Binghui, Z.; Zhong Zhixiong, Z.; Yao, J. J. Chromatogr. A 2006, 1118, 106.

6. Cai, X.; Li, P.; Zhao, Z. Fenxi Huaxue 1987, 15, 971.

7. Davis, J.; Moorcroft, M.J.; Wilkins, S.J. Analyst 2000, 125, 737.

8. Frogg, A.G.; Alonso, R.M. Analyst 1988, 113, 1337.

9. Guerrero, R.S.; Benito, C.G.; Calatynd, J.M. Talanta 1996, 43, 239.

10. Catala-Icardo, M.; Garcia, J.V.; Martinez-Calataud, J. Analyst 2001, 126, 1423.

11. Mesquita, R.B.R.; Rangel, A.O.S.S. Anal. Chim. Acta 2009, 648, 7.

12. Nagaraja, P.; Kumar, M.S.H.; Rangappa, K.S.; Bilwa, L.M. Oriental J. Chem. 1998, 14, 55.

13. Afkhami, A.; Masahi, S.; Bahram. M. Bull. Kor. Chem. Soc. 2004, 25, 1009.

14. Ozmen, H.; Polat, F.; Cukurovali, A. Anal. Lett. 2006, 39, 823.

15. Nair, J.; Gupta, V.K. Anal. Chim. Acta 1979, 111, 311.

16. Tarafder, P.K.; Rathore, D.P.S. Analyst 1988, 113, 1073.

17. Allen, S.E. Chemical Analysis of Ecological Materials, 2nd ed., Blackwell Scientific Publications: Oxford, England; 1989; p 132.

18. Al-Okab, R.A.; Syed, A.A. Talanta 2007, 72, 1239.

19. Bai, L.; Chi, Z. Fenxi Huaxue 2001, 29, 928. 
20. Liu, W.; Ma, W. Guangpuxue Yu Guangpu Fenxi 1999, 19, 636.

21. Pettas, I.A.; Lafis, S. I.; Karayannis, M. I. Anal. Chim. Acta 1998, 376, 331.

22. Pouretedal, H.R.; Nazari, B. J. Chin. Chem. Soc. 2004, 51, 1353.

23. Yue, X.F.; Zhang, Z.Q.; Yan, H.T. Talanta 2004, 62, 97.

24. Hu, W.P.; Dong, X.Z.; He, Z.J. Fenxi Shiyanshi 2005, $24,59$.

25. Zi, Y.; Ling, C. Fenxi Huaxue 2004, 32, 1039.

26. Ensafi, A.A.; Keyvanfard, M. Anal. Lett. 1994, 27, 169.

27. Ensafi, A.A.; Dehaghei, G.B. Fres. J. Anal. Chem. 1999, 363, 131.

28. Montes, R.; Laserna, J.J. Talanta 1987, 34, 1021.

29. Jiang, M.; Jiang, F.; Duan, J.; Tang, X.; Zhao, Z. Anal. Chim. Acta 1990, 234, 403.

30. Bing, L.; Iwatsuki, M; Fukasawa, T. Analyst 1994, 119, 2113.

31. Ashraf, A.M.; El-Shahat, M.F.; Fukasawa T.; Iwatsuki, M. Analyst 1996, 121, 89.

32. Mubarak, A.T.; Mohamed, A.A.; Fawy, K.F.; Al-Shihry, A.S. Microchim. Acta 2007, 157, 99.

33. Khaskheli, A.A.; Mastoi, G.M.; Ansari, I.A.; Khuhawar, M.Y. J. Chem. Soc. Pak. 1997, 19, 118.

34. Ghasemi, J.; Jabbari, A.; Amini, A.; Oskoei, A.G.; Abdolahi. B. Anal. Lett. 2004, 37, 2205.

35. Chen, X.G.; Wang, K.T.; Hu, Z.D.; Zhao, Z. Anal. Lett. 1996, 29, 2015.

36. Mazloum Ardakani, M.; Shishehboreb, M.R.; Nasirzadehb, N.; Hajishabania, A.M.; Tabatabaeeb, M. Can. J. Anal. Sci. Spectrosc. 2006, 51, 117.

37. Harvey, D. Modern Analytical Chemistry, Chapter 6: Equilibrium Chemistry, McGraw-Hill Companies, Inc: USA; 2000; p 172. 